\title{
Identity in Literary Output and Cultural Life in Oman
}

\begin{abstract}
Article entitled Identity in Literary Output and Cultural Life in Oman is a kind of Introduction in showing the beginnings of the cultural activities through establishing Cultural Clubs and newspapers in Oman in $20^{\text {th }}$ century. It presents names of Omani prose writers and poets dealing with Identity in their literary output. Among them: Abū Muslim al-Bahlānī, Abū Surūr Hamīe

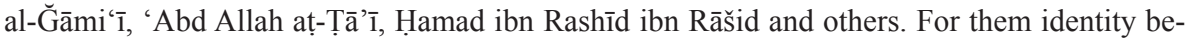
came one of the aims in their literary output to define history, language, culture and religion.
\end{abstract}

Keywords: Oman, literature, prose, poetry, identity

Our present idea of Identity is rather complicated. Though it is commonly known how to use the word properly in everyday discourse, it proves quite difficult to give a short and adequate summary statement that captures the range of its present meanings.

Identity is used to describe the way individuals and groups define themselves and are defined by others on the basis of ethnicity, religion, language and culture. ${ }^{1}$

Identity might be presently used in two senses: social which refers to social category, a set of persons distinguished by rules deciding membership and characteristic features or attributes and personal distinguishing features of a person that form the basis of his dignity or self-respect. In light of the development of humankind, the issue of identity was, is, and will be overwhelmingly important. Undoubtedly, the notion of identity, both individual and collective, is a term that is difficult to be defined. Nowadays, the notion is used in many fields of study. Therefore, we can discuss its meaning in a multidisciplinary context. A major element of identity is one's heritage and behavioural patterns that are culturally rooted. Culture, therefore, is the glue thanks to which we can maintain our own identity. It ensures internal consistency and the sense of unity with members of

\footnotetext{
${ }^{1}$ F. Deng, War of Visions: Conflict and Identities in the Sudan, Washington 1995, p. 1.
} 
a given nation or cultural areas. Identity is a set of different elements; it includes issues concerning religion, history, customs, and language.

When considering the issues concerning the Arab-Muslim identity, we should focus on its important aspect, namely culture as one of its significant elements. Adonis, a prominent thinker and poet, writes about the Arabic culture:

In general, the Arabic culture rests on two piers: language and religion. Because religion for the Muslims is a book that was revealed by God in the Arabic language, thus language and religion are one. Therefore, we can say that religion constitutes an absolute point of reference for the Arabic culture. ${ }^{2}$

One of the main interests tackled in the Adonis' dissertation is the issue of modernity ( hadata) and tradition (turāt) and the interdependency of the two. Furthermore, in his work, the poet goes into the issue of change and its place in Islamic culture. The poet presents the issues from the standpoint of religion and literature, which form the foundations of culture, thereby Arabs' identity.

In his next work Wațan laysa watanan (Mother country that is not a mother country), the poet analyses features of Arab-Muslim identity. It presents the identity (huwiyya) as "that which is constant". Adonis clearly reinforces the language and religion issues as key elements of Arab identity. Because classical Arabian was formed under the influence of the holy book of Islam, for people from the Middle East, religion and language constitute one. This is how the poet reflects on the issue:

It is enough to say that my identity is rooted in the language in which I explain myself. And since it is Arabic, then my creative and human identity is the Arabic identity, limiting itself to the linguistic aspect. Therefore, an Arab is a language creature. ${ }^{3}$

As far as Omani Identity is concerned we observe it in early $20^{\text {th }}$ century with the fall of Ottoman Empire. It was represented by Abū Muslim al-Bahlānī while establishing Imāmate of Oman in 1913 by imām Sālim bin Rāšid al-Hูarūs̄i. His perspective started with tribal unification under the leadership of Nūr ad-Dīn asSālimī. He tried to identify all Omani tribes regardless their differences, genealogy and geographical location. Abū Muslim al-Bahlānī (1860-1920) is an outstanding figure in the pantheon of Omani poets because Omanis identify themselves with his poetry and thoughts. His poetry links between politics and art, elements of the religious discourse and style of modern language. His voice was wide because he came from East Africa (Zanzibar) to Oman and it gives impression of Omanis both sides of the Indian Ocean. Abū Muslim al-Bahlānī poetic talent had produced a large number of poems. His poetry is searching for concept which is related to the transformation of Omani society. ${ }^{4}$

The second generation came at the end of the Imāmate at the end of the 50's represented by many important figures, among them: Abū Sallām al-Kindī, Sulaymān as-Sālimī, 'Abd Allah Halīî̀. In their poems they all give historical description of revival of the nation and identity. 'Abd Allah bin 'Alī Halīlī (1922-

\footnotetext{
2 M. Dziekan, Dzieje kultury arabskiej, Warszawa 2008, p. 14.

3 Idem, Złote stolice Arabów, Warszawa 2011, pp. 74-75.

4 M. al-Ḥārțī (ed.), al-Ațār aš-šsi 'ariyya li-Abī Muslim al-Bahlān̄̄, Freiberg 2010, p. 125.
} 
2000) came from a line whose roots went back far into Oman's past. A family from which many Imams had derived eminent Islamic theologians and tribal leaders. He undertook numerous themes: religious, social and historical in both his lyrical and epic works. Matters that touch the Arab world in general and those confined exclusively to modern-day Oman. 'Abd Allah Halīlī dedicated the first of his poetical works, entitled Min näfidat al-hayāt (From the window of Life) to the Arab nation; brothers who stood up to a common enemy. In the 137-poem long diwān Wahy al- 'abqariyya (The Inspiration of Genius), published for the first time in Muscat in 1979 and reprinted in 1990, he places works that prise the Prophet and wisdom, while also talking about patriotism, historical events and brotherhood. ${ }^{5}$

In the 60's was the end of Al-Bu'sa'īdī state in East Africa. ${ }^{6}$ It effects Omanis in their diaspora in the Arab world, especially Gulf. 'Abd Allah bin Muhammad at-Ṭ̂̄' $\mathbf{1}(1927-1973)$ reflected it in his literary works. His works have had an enormous influence upon the shape of Omani literature and history. He is an author of book al-Adab al-mu 'ạșir fì al-Halīğ al- 'Arabī (The contemporary literature of the Persian Gulf) or Šu 'rā' al-mu 'àșirūn (Modern Poets) trying to introduce Oman and the Gulf Literature Output. He wanted to show Gulf perspective and prove that Gulf is Arab Land, not Persian. He selected the most important figures from Gulf in 60's. He was proud of being Omani.

'Abd Allah aț-Ṭā' ì in his novel aš-Širā' al-kabīr (The great sail) shows the perspective of Gulf Identity through Oman. The Author has chosen a period of Portuguese occupation of Oman which lasted from the beginning of the $16^{\text {th }}$ to the mid of $17^{\text {th }}$ century. ${ }^{7}$ He writes about Imam bin Sultān Ya'rubī who send ship from Basra to Oman to bring people to fight Portuguese in $17^{\text {th }}$ century. There exists within the historical events and admits the historical facts certain pointers for the reader designed to arouse purely patriotic emotions. In recalling moments of glory he wanted to revive the spirit of the heroic past. The Author is proud of his period of Oman's history. The story is written to raise hearts though also constituting a warning about the internal social disintegration which results from the weaknesses of the state. There is emitted from its pages a faith in the strength of unity, both at the level of Oman and the level of the Gulf .

The next generation appeared after gaining power by Sultan Qaboos bin Sa'id in 1970. It shows Omani awareness of consciousness of their identity. New names appear, eg. Abū Surūr Hamīd al-Ğāmi ‘̄ from Samā'il. His literary output is very impressive. Abū Surūr devoted many of his poems to the marvellous history of Oman: 'Umān al-mā poet presents the history of his country over the course of centuries, starting from ancient history, through the adoption of Islam, up until the present day. He does not give historical facts but he gives the reader a sketch of the most important historical events to help understanding their background.

\footnotetext{
5 B. Michalak-Pikulska, Modern Poetry and Prose of Oman 1970-2000, Kraków 2002, pp. 35-37.

6 P. Casey-Vine (ed.), Oman in History, London 1995, pp. 193-206.

7 Ibidem, pp. 385-408.
} 
Modern poets of 90's have different approach to identity. They live in peaceful country so they write about love, beautiful nature, homeland in general. Among them we find: Sa'īd aṣ-Șaqlāwī, Sayf ar-Raḥbī or Muḥammad al-Harțī. Their poems played an important role in showing Identity of Omanis despite different expressions and language. They all share their love for Oman. They write poems dedicated to their beautiful homeland because they all share the same habits, feelings, language and religion.

An important moment in the development of Oman and its Identity was the founding of cultural-literary clubs, such as: the Literary Club (Al-Muntadā AlAdabī) in Muscat, the Cultural Club (An-Nādī at-taqāfĩ) in Muscat, or the Cultural Centre (Al-Markaz at-taqāfî) in Salalah, in which lively cultural and literary activities have been carried out from the beginning. A group of educated Omanis founded in 1974 the National Cultural Club in Muscat (An-Nādī Al-Wațan̄̄ attaqāfì). The Club organised many cultural events in order to gather Omanis. It published a monthly bulletin entitled At-taqāfa al-ğadīda (New Culture). In 1983 the University Club (An-Nādī Al-ğāmi ‘̄̄) was founded. Following the foundation of the Sultan Qabus University in 1986 its name was changed to the Cultural Club (An-Nādī at-taqāfî). The aim of the institution was the organisation and tightening of cultural and social links between Omani young people, as well as the development of young literary talents. Besides, the Club was to develop and co-ordinate co-operation and contacts with organisations and cultural and academic centres within Oman and abroad. Even today its activities concentrate on the organising of lectures, symposia, poetry and literary evenings, covering such areas as: religion, philosophy, science and the arts. It possesses its own impressive library. The club members: university graduates, writers, poets, readers, people from the world of art and culture are able to develop their academic and artistic interests in many workshops including photograph, art and music. Lectures by eminent Arab and non-Arab writers, literary critics, thinkers and politicians are often organised there. The Club published in December 1991 its first publication containing a description of the most important events that have taken place in the Club. The Literary Club (Al-Muntadā Al-Adabī) was founded in 1985 in Muscat with the aim of creating an appropriate literary base that could promote and help the talents of Omani writers and poets. The Club possesses a sizeable library and a large theatre where poetry evenings and literary symposia are organised. The Club organises conferences on a regular basis that are devoted to the creative work of Omani writers. Besides, it systematically organises conferences that are dedicated to particular Omani towns. Sohar over the Centuries or Dhofar-Between the Past and the Present. All information on the Club's activities can be found in the bulletin Al-Muntad̄̄ Al-Adab̄̄ Fi' 'àliyāt wa manāšit (The Literary Club. Events and Activities). ${ }^{8}$

The initiator behind the founding of the Association of Omani Women (Ğama‘yyat Al-Mar'a al-'Umāniyya) in Muscat was Zamzam Hasan Yūsuf Makkī. The aims of the organisation are as follows: to raise the social, cultural and

\footnotetext{
${ }^{8}$ On the basis of information contained in: Fì riḥāb Al-Muntadā Al-Adabī, Muscat 1989.
} 
health level amongst Omani women and children, to increase the role of women in programmes of social development in Oman and their participation in the development of schooling and cultural development, to make women conscious of the role of upholding religious traditions that are rooted in society, to co-operate with women's organisations abroad, to take part in national and cultural events. The Association, so active in so many areas, also produces its own journal entitled 'Umäniyya (Omani Woman) which deals chiefly with women's issues. ${ }^{9}$ This is the first women's magazine to be published in Oman. It first came out at the beginning of the 1980s. During the years 1986-1989 the function of editor-in-chief was

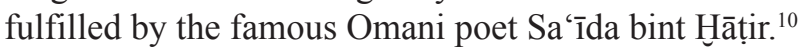

Numerous public libraries have also been founded, both general and specialist in nature, possessing sizeable book collections from various areas of knowledge and science. The most important include: The Muslim Library (Al-Maktaba AlIslāmiyya) founded in 1980, The Technical Library (Al-Maktaba Al-Fanniyya) set up in 1990, the Sultan Qaboos University Library (Maktabat Ğāmi'at AsSultạn Qābūs), The Institute of Public Administration Library (Maktaba Ma'had Al-Idāra Al-'āmma), The Library of the British Council (Maktabat Al-Mağlis attaqāầ Al-Brīṭānī).

All this cultural activities gathered and united Omanis in order to share interests in Omani history, customs and literature. Omanis have desire for group distinction, dignity and place within historically discourse.

As everywhere in the world, the press has played a very important role in the development of contemporary Omani literature. Its blooming was caused by the return of grant holders and educated Omanis from abroad at the beginning of the 1970s, as well as the development of academic-cultural centres within Oman. Among the titles worthy of note are the dailies: 'Umān, Al-Watan and $A \check{s}-\check{S}$ abiziba. New literary and cultural magazines initially appeared only sporadically like, for example, $A l-\dot{G} a d \bar{i} r$ and $A s-S i r a \bar{g} \breve{. ~}$

The cultural and literary quarterly Nizwa appeared on the $18^{\text {th }}$ February 1994. The editor-in-chief is the prominent Omani poet and thinker Sayf Ar-Raḥbī. Nizwa is considered to be one of the best journals in the Arab world. Many young Omanis write for it. Outstanding figures from Arab literary and cultural life are often invited to contribute. There is room for literary, cultural, philosophical and artistic themes, for dialogue, criticism, photographs as well as journalistic pieces about Oman. The reader can also find there the literary attempts of young Omanis accompanied by a commentary. ${ }^{11}$

Information plays a vital role in the Identity of a modern state. It brings many benefits to the people and gives an added dimension to the quality of life and wellbeing of a nation. It is therefore hardly surprising that as much attention has been paid to advancing the media in Oman as to any other aspect of the country's rapid and successful development.

\footnotetext{
930 'āmān... 'ata' mutawāṣil - Ğama 'yyat Al-Mar'a al- 'Umāniyya bi-masqaț, Muscat 2000.

${ }^{10}$ On the basis of information received from 'Āida Salīm Al-Hağarī.

11 On the basis of information and interview with Țālib Al-Ma'marī carried out in Muscat in 2011.
} 
The creation of newspapers and literary journals led directly to the development and blossoming of Omani cultural and literary life. Around them literary figures concentrated in order to publish their works. The Omani press created conditions for the publication of all writers and poets. Their works covered a wide range of positions and attitudes in relation to the changes the country underwent. The variety of journals allowed for the inclusion in public life of intellectual writers of various social, philosophical and esthetical orientations. It was, and is, true to Omani national heritage helping with National Identity.

I would like to underline that cultural life and history was very important for developing identity in Oman. Literature played role as promoter of identities of Omanis.

The Omani prose has a short history in relation to other Arab countries of the Arabian Gulf though one can notice on the whole a great personal interest on the part of the writers in this particular literary genre. This literary form was liked by young Omani writers of the 1980 s, for according to them, it was to be the short story itself that was to give a current account of the social, political and cultural situation in Oman which was changing daily following the taking of power in 1970 by Sultan Qabūs ibn Sa'īd. The national identification of Omanis with Oman became one of his basic aims. This aim was seized upon by contemporary Omani writers who perceived easily the importance of this for the development of their country.

'Alī Al-Ma'marī in his short story Ziyāna deals with national identity. The main role is played not by the character but by Oman itself and the individual letters, in Arabic, forming its name: 'ayn, mim, alif and nun are interpreted in the following way:

You are like 'ayn i.e. an eye which sees, and you are like mim which is support for one's back, and you are like alif which requires a spine and finally you are like nun - a sign of peace and safety. ${ }^{12}$

The inhabitants of Oman love their beautiful country and often travel around it. Hālid Al-Fārisī reflected his love for his native Muscat in a longer short story published in 1995 and entitled Musqat... tugiannī (Muscat Sings). Within the work he writes:

Love for the homeland returns honour to a man within which he perfects himself and his sense of responsibility in relation to his beloved Oman. ${ }^{13}$

Hâlid is proud of being an Omani, he identifies himself with everything that reminds him of his native country and town with the words:

My town is blooming and enchanting in its beautiful and bewitching coast, at times lost behind the mountainous chains. ${ }^{14}$

He describes numerous districts of Muscat, which were once separate towns. The author himself says that "it is the song of an Omani to his beloved country".

\footnotetext{
12 'A. al-Ma'marī, Ziyāna, [in:] Mufāăg'at al-ahibba, Ribat 1993, p. 43.

${ }_{13}$ H. Al-Fārisī, Musqat ... tuġannī, Muscat 1995, p. 51.

${ }^{14}$ Ibidem, p. 24.
} 
Omanis often within the pages of their modern literature return to their own history. In this way the short story lent itself to the formation of historical consciousness. The facts contained in them create an image of Oman's history. They stress the role of the individual in their work. Writers especially like the subject of the heroic struggles against Portuguese rule, who in 1507 took the important ports of Muscat and Oman. From the $17^{\text {th }}$ century Omani tribes under the leadership of imam Nașir ibn Muršid took the important ports: Matrah and Sur as well as holding the town and fortress at Muscat which finally led to the end of Portuguese domination in 1650. Under the rule of Ya'rūbī Oman became a strong state which extended its authority to the eastern coast of Africa: Zanzibar, Mombassa and Mogadish.

The writings of Hamad ibn Rashīd ibn Rāšid are characterised by an interest in history as the source of the consciousness and patriotism of today's generation

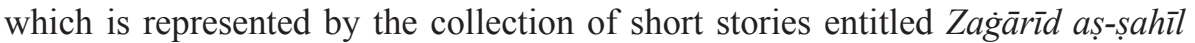
(The Neigh of the Horses). He tells the truth about man and history in many ways, for example in the short stories: 'Azzān (Azzan) and Tadhiya (The Victim). History intrudes into his world, names atrocities, yet lays bare that which is rooted in man. 'Azzān is the story of men making their way to fight the Portuguese. Women and other men proudly see them off. The life of the hero of the title 'Azzan is short:

Azzan went at the back of the group as the youngest. He said farewell to his mother with a sense of regret and happiness... the despair of parting and the joy of war with the enemy. He was a youth in his prime. His face showed he came from the hills. As a rule he was quiet and sad following the death of his father who had fallen in one of the battles with the Portuguese enemy. He had ceased being a child when he could fasten his trousers. He walks with a determined stride with the group in the direction of the beach. His mother watches him $[\ldots]$ touches her belly heavy with pregnancy... her fallen husband's final gift. ${ }^{15}$

The author endowed his young hero with courage, and faithfulness to his very self, the fatherland, God and the determination needed for the realisation of the task. Finally his young life is cut short by death. At the same time that he is dying his mother is giving birth to his brother. Therefore a successiveness of generations is preserved in order to defend the beloved homeland.

Hamad ibn Rashīd ibn Rāšid describes in the short story Farhat al-luqyā (The Joy of Meeting) another return to the home country - the return of a just man of the sea, who loves his own country, culture and religion. The characteristic feature of Hamad's craft is the gathering of a lot of information within a limited area, fast and lively illustrations. The descriptions of the characters are short, the metaphors abridged, the array of the sentences terse, sometimes even journalistic. No less striking is the immense poetry of illustration; as if under the swift stroke of a brush there appear landscapes with sardines caught by white gulls. People hum tunes and a boat after its half-yearly cruise reaches the bank.

White gulls fly over the dried sardines... some of them steal the fish dancing in the sunlight [...] The fishermen work hard in order to free the net from the catch. They sing the old songs Al-gaws [...] Each works hard. [...] They play the old songs on the radio, everyone

${ }^{15}$ Ḥ. Rashīd ibn Rāšid, 'Azzān, [in:] Zag̀āāìd aṣ-șahīl, Muscat 1990, p. 21. 
is in raptures 'I always remember you, the setting of the sun... those whispers amongst the palms... you about your love and I about mine... meetings are the cure for all disease... Pray to Allah... Pray to Allah... about my dear love.' From a distance a group of women and children wait for the arrival of a ship with presents and goods. ${ }^{16}$

It is a beautiful return to meet those who consider themselves to be real Omanis. The author presents their hard work, troubles and joys which are sympathised with by the nature that surrounds them. They are always accompanied by the song of their own culture and customs, while at the same time expressing a longing for family and fatherland. The short story is an example of an identification of the Omanis as a sea-faring people - the sea which has always been their ally giving work, food, relaxation and joy.

'Alī Al-Kalbānī in the short story Baqiyya min ta' $m$ (Bait) undertakes the subject of hard work at sea. The hero here is a poor fisherman who sets off every morning to fish at dawn. He shares his difficult life with God through prayer. He is a simple subject of Oman, he works from morning to eve with the other members of the village, he prays and retires early. We observe his helplessness and loss in relation to fate:

Yet for Hamdan one day in no way differed from the next. As equally for him as for the majority of the inhabitants of the village each approaching day recalled all those that had passed. For them fishing begins every day before dawn and ends before afternoon prayer. Later work on the small holding right up until the setting of the sun, supper, prayer, after which they sit down to talk while drinking coffee and chewing dates. After which they go to bed in order to generate strength for the next trip out to sea. Their lives revolve in a routine. The most interesting thing that can occur to them is when they can exchange information about what has happened at sea, in the fields or in the village. This is the only thing that occupies their thoughts. They are happy with this way of leading their lives, lives which they love despite the labour and misfortune they offer them. ${ }^{17}$

Omanis are linked from their childhood with the sea, as equally with the desert. They therefore have especial sentiment for the palms which as Hamad ibn Rashid ibn Rāšid says survive all. They do not even consider crude oil to be something special because this 'will not last eternally'. In the short story An-nahla as-sagìra (The Little Palm) Hamad describes the cultivation of palms and their significance for the country, for which they constitute riches. The author speaks in the words of the grandfather to whom the work is dedicated:

Son, your grandfather is on his way to the grave. My sadness is caused by that little palm. Who is going to care for it after my death? Who will satisfy its thirst and protect it from the ravages of the elements... and....? ${ }^{18}$

The author ponders over the younger Omani generation as to whether it will be sentimental and whether it will understand the values which generated respect for its grandfathers? The short story shows the way of thinking and mentality of the older generation through the functioning of old ties and the birth of new ones.

${ }^{16}$ Ḥ. Rashīd ibn Rāšid, Farhat al-luqyā, [in:] Zag̀ārīd aș-ṣahīl, p. 12.

17 'A. al-Kalbani, Baqiyya min ța 'm, [in:] Șirā'ma 'a al-amwāğ, Muscat 1987, p. 18.

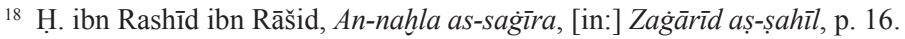


Omani writers through a modern look at the past yearn to enrich national culture, for revitalising history is for them reaching for one's own roots. Different, even chronologically removed events, unite the similarity of human attitudes. Often the authors search for their own social origins within their short stories. They are equally interested in religious problems, the mutual influence of different cultures, the relations between the individual and society at various times and in various parts of the world. They experience and view historical facts from various sides. They try to show the role of the individual against the expanse of history. When some die or perish in struggle there instantly starts the life of others in which way the integral vision of people's fate is created. Making use of freedom in the expressing of thoughts and views Omani writers undertake an emotional form of accounting with the past in their works. Yet this settling of accounts always has a positive undertone 'for the comforting of hearts'. Other subjects and chains of thought are continued e.g. the Omani deep-rootedness in village culture. The turning of attention towards the subject of rural people who are unable to adapt to life in the town is a manifestation of distrust in the overly quick changes in civilisation and doubts as to the new socio-economic values. No less however the main aim of the short stories is to find within one's own culture common national and universal values, for only from this perspective is it possible to perceive the sense of the changes in customs and society.

\section{Bibliography}

Deng F., War of Visions: Conflict and Identities in the Sudan, Washington 1995.

Dziekan M., Dzieje kultury arabskiej, Warszawa 2008.

Dziekan M., Złote stolice Arabów, Warszawa 2011.

Michalak-Pikulska B., Modern Poetry and Prose of Oman 1970-2000, Kraków 2002.

Al-Ma'marī 'A., Mufäğ 'at al-ahibba, Ribat 1993.

Al-Fārisī H.., Musqaț... tugiannī, Muscat 1995.

Rashīd ibn Rāšid Ḥ., Zag̀ārīd aṣ-ṣahīl, Muscat 1990.

Al-Kalbani 'A., Baqiyya min ța 'm, [in:] Șirā'ma 'a al-amwāğ, Muscat 1987. al-Ḥārt̄ī M. (ed.), al-Ațār aš-ši 'ariyya li-Abī Muslim al-Bahlān̄̄, Freiberg 2010. Casey-Vine P. (ed.), Oman in History, London 1995. 